\title{
ANALISIS HUBUNGAN PARAMETER CUACA TERHADAP KONSENTRASI POLUTAN (PM2.5 DAN CO) DI WILAYAH JAKARTA SELAMA PERIODE WORK FROM HOME (WFH) MARET 2020
}

\author{
Analysis of The Weather Parameters Relationship on Pollutant \\ Concentrations (PM2.5 and CO) in Central of Jakarta during Work from \\ Home (WFH) March 2020
}

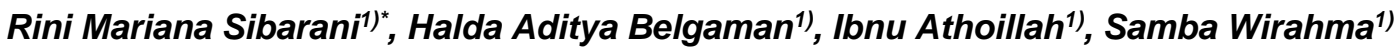 \\ 1) Balai Besar Teknologi Modifikasi Cuaca - Badan Pengkajian dan Penerapan Teknologi, Gedung Ir. \\ Mohammad Soebagio, GEOSTECH (820), Kawasan PUSPIPTEK, Serpong, Tangerang Selatan \\ *Email : rini.mariana@bppt.go.id
}

\begin{abstract}
Intisari
Selama ini Jakarta dikenal dengan kota berpolusi dengan indeks pencemaran udara yang cukup tinggi. Salah satu penyebab pencemaran udara adalah polutan partikulat (PM2.5) dan gas CO yang berasal dari pembakaran tidak sempurna. Pada masa pandemi Covid-19, pemerintah menerapkan kebijakan Pemberlakuan Pembatasan Kegiatan Masyarakat (PPKM) untuk menekan jumlah penularan virus Covid-19. Jakarta Pusat sebagai salah satu kota yang melaksanakan kebijakan PPKM mewajibkan perkantoran yang ada untuk menerapkan Work From Home (WFH). Jumlah konsentrasi polusi udara PM2.5 pada periode WFH Maret 2020 tidak jauh berbeda dibandingkan lima tahun sebelumnya. Sedangkan konsentrasi CO pada periode yang sama mengalami penurunan dibandingkan lima tahun sebelumnya. Hasil analisis hubungan antara pengaruh parameter cuaca dengan konsentrasi polutan menunjukkan pengaruh parameter cuaca kurang signifikan terhadap konsentrasi $P_{2.5}$ dan gas $C O$. Nilai R-Square adj antara beberapa parameter cuaca terhadap konsentrasi PM2.5 dan konsentrasi CO cukup kecil. Hal ini menunjukkan bahwa pengurangan nilai konsentrasi PM2.5 dan gas CO bukan dipengaruhi oleh parameter cuaca. Faktor lain yang diduga memengaruhi konsentrasi PM2.5 dan gas CO adalah kegiatan manusia seperti WFH sehingga terjadi pengurangan aktivitas masyarakat untuk pergi ke kantor.
\end{abstract}

Kata Kunci : CO, PM2.5, Parameter Cuaca, Pencemaran Udara, Work From Home.

\begin{abstract}
Jakarta is known as a polluted city with a high air pollution index. One of the air pollution causes is particulate pollutants (PM 2.5) and CO from incomplete combustion. During the Covid-19 pandemic, the government implemented a policy of Community Activity Restrictions, known as PPKM, to reduce the number of transmissions of the Covid-19. As one of the cities implementing the PPKM policy, Central Jakarta requires offices to implement Work From Home (WFH). The total PM2.5 air pollution concentration in the March 2020 WFH period was not much different from the previous five years. However, the CO concentration in the same period decreased compared to the last five years. Relationship analysis between the influence of weather parameters and pollutant concentrations shows that weather parameters are less significant on PM2.5 and CO concentration. The R-Square adj between several weather parameters on the concentration of PM2.5 and the concentration of $C O$ is small. It means that weather parameters do not influence the reduction in the concentration of $P M_{2.5}$ and $C O$. It is assumed that the PM2.5 and CO concentrations decreased due to fewer human activities in the office and public areas.
\end{abstract}

Keywords: Air Pollution, CO, PM2.5, Weather Parameters, Work From Home.

\section{PENDAHULUAN}

Wilayah Jakarta memiliki luas daratan $661.52 \mathrm{~km}^{2}$ dan berbatasan langsung dengan beberapa wilayah seperti Depok, Tangerang, Bogor, dan Bekasi. Sebagai pusat pemetintahan dan pusat perekonomian membuat Jakarta sering dikunjungi masyarakat dari berbagai wilayah, baik menggunakan transportasi umum maupun transportasi pribadi. Banyaknya jumlah transportasi di Jakarta mengakibatkan peningkatan polusi udara di wilayah tersebut. Selain itu, industrialisasi yang ada sekitar Jakarta juga menambah peningkatan polusi udara (Pemprov DKI 2017). 
Menurut Parker (1976), polusi udara merupakan proses masuknya substansi atau kombinasi dari berbagai substansi ke dalam udara yang mengakibatkan gangguan pada kesehatan manusia atau bentuk kehidupan yang lebih rendah. Polusi udara ini bersifat menyerang, dan merugikan tubuh manusia. Total Suspended Particulate (TSP) terdapat di udara dengan ukuran antara kurang dari 1 mikron hingga 500 mikron. Ukuran yang kecil tersebut dapat masuk ke dalam sistem pernapasan atas dan memberi dampak buruk bagi kesehatan.

Particulate Matter (PM) merupakan klasifikasi fisik umum partikel yang ditemukan di udara, seperti debu, kotoran, jelaga, dan asap. PM bukan merujuk pada entitas kimia tertentu tetapi merupakan campuran partikel dari sumber yang berbeda dengan berbagai ukuran, komposisi, dan sifat (Vallero 2014). Definisi standar dari $\mathrm{PM}_{2.5}$ adalah konsentrasi massa dari PM untuk partikel yang melewati inlet atau pipa saringan selektif yang memiliki efisiensi $50 \%$ pada diameter aerodinamik sebesar 2,5 $\mu \mathrm{m}$. Ukuran $\mathrm{PM}_{2.5}$ yang sangat kecil dan berbahaya dapat masuk ke dalam alveoli paru-paru dan memasuki sistem sirkulasi darah. Hal ini menyebabkan partikulat masuk menuju organ-organ lain dan menyebabkan kerusakan pada sistem pernapasan (Xu, D. Q dan Zhang, W. L., 2004). Peraturan Pemerintah RI No. 41 Tahun 1999 tentang Pengendalian Pencemaran Udara menetapkan baku mutu udara ambien nasional konsentrasi $\mathrm{PM}_{2.5}$ sebesar $65 \mu \mathrm{m} / \mathrm{m}^{3}$ untuk ratarata 24 jam, dan untuk udara di dalam ruangan (indoor) baku mutu $35 \mu \mathrm{m} / \mathrm{m}^{3}$ sesuai dengan Permenkes No. 1077 tahun 2011.

Menurut Ocak dan Turalioglu (2008), CO merupakan gas yang memiliki peranan penting di troposfer serta dihasilkan oleh sumber alami maupun antropogenik. Sumber alami penghasil CO terdiri dari oksidasi metana dan hidrokarbon alami, emisi laut, serta emisi dari vegetasi. Sumber tersebut merupakan sumber yang paling dominan untuk daerah pedesaan, sehingga di lokasi terpencil, CO merupakan salah satu partikel yang paling dominan untuk produksi ozon fotokimia. Lain halnya pada daerah perkotaan, sumber antropogenik seperti pembakaran bahan bakar fosil, kegiatan industri, kendaraan bermotor, pembakaran biomassa, dan oksidasi hidrokarbon juga ikut memperbanyak jumlah konsentrasi $\mathrm{CO}$. Lifetime $\mathrm{CO}$ adalah sekitar 1-3 bulan, mewakili laju yang lambat dari pencampuran dan konsumsi melalui reaksi dengan $\mathrm{OH}$ (Ocak dan Turalioglu, 2008; Aneja et al., 2000; Parrish et al., 1991)

Beberapa parameter cuaca (suhu udara, kecepatan angin, lama penyinaran matahari, curah hujan, dan indeks labilitas) dapat menentukan kelabilan atmosfer. Kondisi atmosfer yang labil dapat mengangkat partikel-partikel yang terlepas di udara hingga ke level yang tinggi, sehingga dapat membuat kondisi udara di permukaan menjadi bersih. Data vertikal atmosfer yang diperoleh dari data Radiosonde dapat digunakan untuk melihat kelabilan atmosfer (Zahroh et al., 2017). Data Radiosonde dari stasiun BMKG Jakarta Kemayoran dapat mewakili kondisi atmosfer di wilayah tersebut. Beberapa indeks labilitas dapat diperoleh dari data Radiosonde dengan memperhatikan suhu udara dan kelembapan udara vertikal.

Convective Available Potential Energy (CAPE) merupakan jumlah energi yang tersedia di atmosfer dan digunakan untuk pengangkatan massa udara secara adiabatik, sedangkan Showalter Indeks (SI) dan Lifted indeks (LI) merupakan parameter yang dapat digunakan untuk menentukan tingkat stabilitas atmosfer. Masing-masing nilai SI maupun LI mempunyai nilai ambang batas untuk memprakirakan potensi thunderstorm. K-Indeks merupakan suatu ukuran potensi badai akibat gerak konvektif yang diukur berdasarkan selang suhu vertikal, dan kelembapan atmosfer. Total-Total Index (TT) adalah salah satu indeks yang dapat menentukan proses konveksi. TT ini merupakan gabungan dari indeks vertical totals dan cross totals, serta Severe Weather Threat Index merupakan indeks untuk melihat potensi cuaca buruk dengan tetap memperhitungkan mekanisme lain yang mempengaruhinya.

Pada awal Maret 2020, di Indonesia telah ditemukan kasus pasien yang terjangkit virus COVID-19. Adanya wabah tersebut menyebabkan berbagai macam aktivitas seperti sekolah dan perkantoran harus dilakukan dari rumah atau biasa dikenal dengan istilah WFH. Kegiatan WFH yang berlangsung pada periode 16-31 Maret 2020 sesuai Surat Edaran Menteri PANRB No.19 Tahun 2020 membuat kegiatan masyarakat yang bekerja di kantor berkurang. Hal ini memberikan dampak positif terhadap keadaan polusi udara di Jakarta (Rizi et al., 2019). Penelitian ini mengkaji penyebab pengurangan nilai konsentrasi polutan $\left(\mathrm{PM}_{2.5}\right.$ dan $\left.\mathrm{CO}\right)$ di wilayah Jakarta Pusat sebagai efek dari WFH dan pengaruh berbagai parameter cuaca terhadap konsentrasi $\mathrm{PM}_{2.5}$ dan $\mathrm{CO}$.

\section{METODE}

Lokasi yang menjadi wilayah penelitian ini adalah Jakarta Pusat dengan luas wilayah 48.13 $\mathrm{km}^{2}$ dengan jumlah kepadatan penduduk 23.801 jiwa/km² (Pemprov DKI 2017). Wilayah Jakarta Pusat (Gambar 1) sebagai pusat pemerintahan dan perekonomian telah menerapkan pembatasan aktivitas manusia untuk mengurangi penyebaran virus Covid-19 pada periode bulan Maret 2020. Sebagian besar kegiatan masyarakat seperti kegiatan belajar dan perkantoran dilakukan dari rumah. 


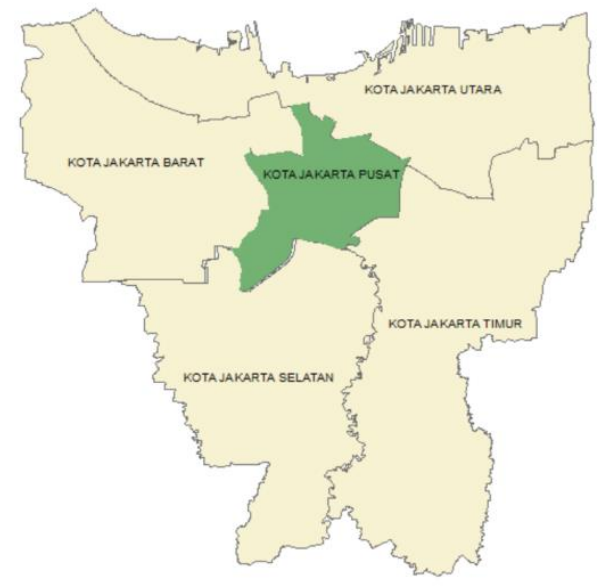

Gambar 1. Peta Provinsi DKI Jakarta

Data yang digunakan dalam penelitian ini adalah data konsentrasi polutan ( $\mathrm{PM}_{2.5}$ dan $\mathrm{CO}$ ) yang diambil dari www.airnow.gov, data indeks global, dan data parameter cuaca (curah hujan, suhu, kelembapan udara, dan angin) dari BMKG.

Metode analisis dilakukan dengan menganalisis indeks Indian Ocean Dipole (IOD) yang merupakan fenomena naik turunnya suhu muka laut di wilayah barat dan timur Samudera Hindia. Indeks IOD yang bernilai negatif akan menambah intesitas curah hujan di Indonesia bagian barat. Sedangkan indeks IOD yang bernilai negatif akan berdampak sebaliknya.

Selain itu, indeks labilitas atmosfer juga dianalisis untuk mengetahui kondisi atmosfer di wilayah Jakarta pada bulan Maret 2016, Maret 2017, Maret 2018, Maret 2019, dan Maret 2020. Hubungan parameter cuaca dengan konsentrasi polutan $\mathrm{PM}_{2.5}$ dan $\mathrm{CO}$ di udara dianalisis dengan metode korelasi dan regresi berganda untuk melihat keterkaitan kegiatan WFH terhadap pengurangan konsentrasi polutan di wilayah Jakarta Pusat. Peubah bebas yang digunakan adalah suhu udara, kelembapan udara, kecepatan angin, lama penyinaran, dan curah hujan, sedangkan peubah terikat adalah konsentrasi polutan ( $\mathrm{PM}_{2.5}$ dan $\left.\mathrm{CO}\right)$.

\section{HASIL DAN PEMBAHASAN}

\subsection{Analisis Kondisi Atmosfer Wilayah Jakarta Periode Maret (2016-2020)}

Indonesia sebagai negara tropis memiliki dua musim, yaitu musim kemarau dan musim hujan. Sebagian besar wilayah Indonesia, musim hujan terjadi pada periode bulan Oktober-April dan musim kemarau terjadi pada periode bulan Mei-September. Periode ini dapat berubah jika fenomena global seperti El-Nino, La-Nina, Sirkulasi Timur-Barat (Walker Circulation), Sirkulasi Utara-Selatan (Hadley Circulation), serta beberapa sirkulasi karena faktor lokal lainnya menguat. Menurut Yananto dan Sibarani (2016), indeks IOD yang bernilai negatif pada saat terjadi monsun barat mengakibatkan terjadinya peningkatan nilai intensitas hujan di Jakarta. Menurut Athoillah et al. (2017), pada pertengahan tahun 2015 hingga awal tahun 2016 di wilayah Jakarta mengalami fenomena El-Nino namun pengaruh monsun barat dan indeks IOD yang bernilai negatif mengakibatkan wilayah Jakarta tidak mengalami penurunan intensitas hujan yang terlalu signifikan.

Indeks IOD pada periode bulan Maret 2017September 2021 menunjukkan dominasi nilai IOD negatif pada bulan Maret setiap tahunnya yang ditunjukkan garis putus-putus merah (Gambar 2). Hal ini menunjukkan bahwa pada lima periode tersebut kondisi atmosfer masih cukup labil dan masih memiliki peluang adanya penambahan jumlah intensitas hujan.

Sebaran indeks labilitas atmosfer wilayah Jakarta periode bulan Maret 2016, 2017, 2018, 2019, dan 2020 dengan batas ambang indeks ditunjukkan pada Gambar 3. Data diperoleh dari Radiosonde milik BMKG wilayah Jakarta. Selama periode tersebut, kondisi atmosfer di wilayah Jakarta dominan labil menengah, dengan nilai $\mathrm{LI}$ antara -2 sampai -6 dan nilai SI antara -4 sampai 4.

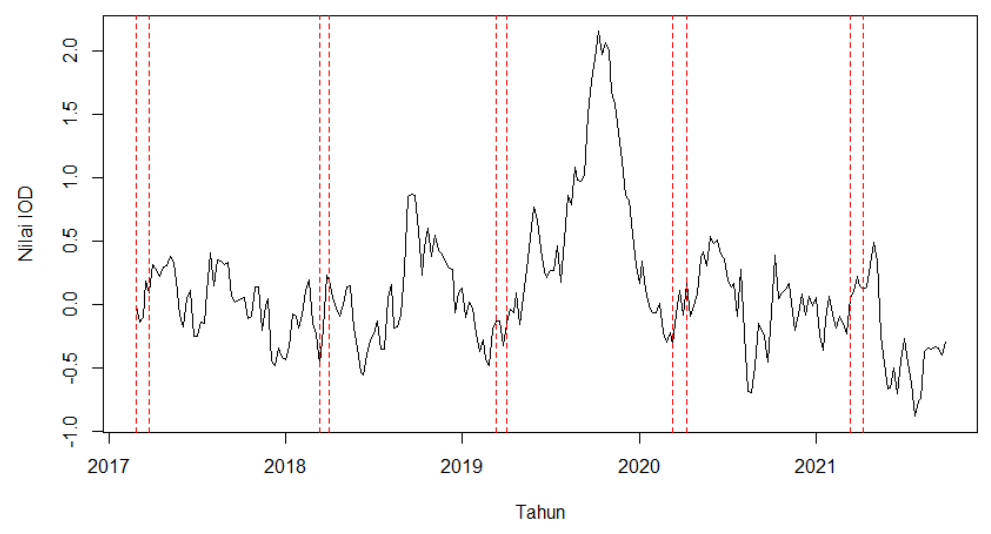

Gambar 2. Nilai IOD periode Maret 2017-September 2021 (garis putus-putus menunjukkan indeks IOD pada bulan Maret setiap tahunnya). 

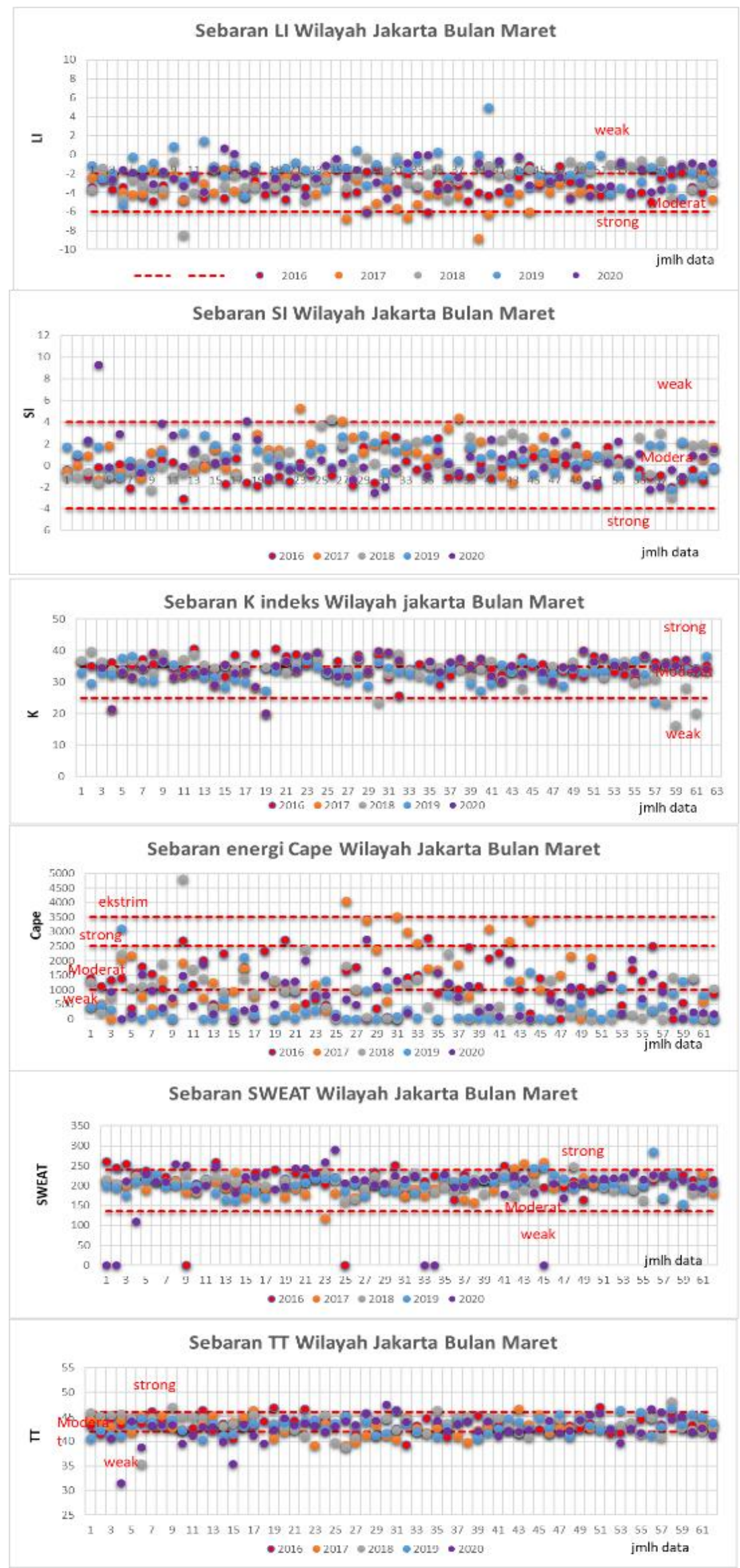

Gambar 3. Indeks labilitas wilayah Jakarta periode Maret 2016, 2017, 2018, 2019, dan 2020. 
Nilai $K$-Index dominan pada kategori menengah hingga kuat (25-40). Kondisi tersebut menunjukkan bahwa pada bulan Maret dari tahun 2016-2020 kondisi atmosfer Jakarta cukup konvektif dan labil. Sweat Index dan Total-Totals Index pada periode tersebut dominan berada pada kategori menengah. Sweat Index pada rentang 125-239 dan Total-Totals Index berada pada rentang nilai 40-46. Kondisi ini juga menunjukkan wilayah Jakarta cukup labil dan dominan pertumbuhan awan cumulus hingga cumulonimbus.

\subsection{Analisis Konsentrasi Polutan Wilayah Jakarta Pusat Periode Maret}

\subsubsection{Konsentrasi $P M_{2.5}$}

Gambar 4 memperlihatkan grafik kumulatif konsentrasi harian polutan $\mathrm{PM}_{2.5}$ wilayah Jakarta periode bulan Maret. Jika dibandingkan tahun sebelumnya, konsentrasi $\mathrm{PM}_{2.5}$ cenderung lebih tinggi pada awal dasarian I bulan Maret 2020 dan mulai mengalami pengurangan konsentrasi pada akhir dasarian I bulan Maret 2020, meskipun terjadi penurunan konsentrasi $\mathrm{PM}_{2.5}$ dan terus berkurang hingga akhir Maret 2020. Meskipun demikian jumlah kumulatif konsentrasi paling rendah terjadi pada Maret 2019, karena pada dasarian III bulan Maret 2019 terlihat peningkatan konsentrasi cukup landai dari tanggal $19-25$ Maret 2019. Hal ini menunjukkan bahwa konsentrasi polusi udara $\mathrm{PM}_{2.5}$ pada masa WFH tahun 2020 tidak jauh mengalami penurunan selama adanya kegiatan pembatasan aktivitas manusia di ibukota.

Menurut Zhang et al. (2015), parameter meteorologi adalah salah satu faktor penting yang mempengaruhi kualitas udara perkotaan. Suhu udara, kelembapan relatif, serta kecepatan dan arah angin dianggap sebagai faktor utama karena dapat mempengaruhi proses dispersi, mekanisme penghapusan, dan pembentukan partikel atmosfer. Proses-proses tersebut dapat memainkan peran penting dalam mengendalikan konsentrasi polutan udara. Selain itu menurut Shukla et al. (2008), parameter hujan juga dapat mempengaruhi konsentrasi polutan udara karena dapat menghilangkan polusi gas dan pengendapan partikulat melalui proses kimia atmosfer.

Selama bulan Maret 2020, konsentrasi $\mathrm{PM}_{2.5}$ berada pada rentang nilai $15-55 \mu \mathrm{g} / \mathrm{m}^{3}$. Berdasarkan Peraturan Pemerintah No.41 Tahun
1999 tentang Pengendalian Pencemaran Udara, ketentuan baku mutu udara ambien nasional konsentrasi $\mathrm{PM}_{2.5}$ untuk 24 jam adalah $65 \mu \mathrm{g} / \mathrm{m}^{3}$. Pada periode Maret 2020 PM$_{2.5}$ di wilayah Jakarta Pusat masih dalam kategori aman (Gambar 5a).

Hasil korelasi antara parameter cuaca dan konsentrasi $\mathrm{PM}_{2.5}$ terdapat beberapa parameter cuaca yang memiliki korelasi namun tidak terlalu besar (Gambar 5b). Nilai korelasi dari tiap parameter terhadap konsentasi $\mathrm{PM}_{2.5}$ adalah parameter kelembapan udara $(\mathrm{RH})$ sebesar 0.28 , parameter perbedaan suhu udara $(\Delta \mathrm{T})$ sebesar 0.23, parameter hujan (RR) sebesar -0.29 , parameter lama penyinaran (SS) dan kecepatan angin maksimum (FF) sebesar 0 .

Metode regresi berganda digunakan untuk melihat pengaruh beberapa parameter cuaca terhadap konsentrasi $\mathrm{PM}_{2.5}$ di wilayah Jakarta Pusat. Nilai $R$-square adj digunakan untuk melihat pengaruh dari peubah bebas (parameter cuaca) terhadap konsentrasi $\mathrm{PM}_{2.5}$ karena nilainya lebih robust dibandingkan nilai $R$-square saja. Hasilnya diperoleh nilai $R$-Square adj cukup kecil dan model regresi yang dihasilkan tidak signifikan, kecuali pada tahun 2016 model regresi yang diperoleh cukup signifikan pada taraf signifikansi $10 \%$ dengan nilai $R$-square adj sebesar 0.2101 .

Hal ini memperlihatkan bahwa parameter cuaca bukanlah faktor utama yang mempengaruhi konsentrasi $\mathrm{PM}_{2.5}$ di wilayah Jakarta Pusat. Nilai $R$-square adj yang kecil menunjukkan bahwa pengaruh cuaca sangat kecil terhadap konsentrasi $\mathrm{PM}_{2.5}$ di wilayah Jakarta hanya sekitar $21 \%$ pada tahun 2016. Sedangkan pada tahun 2020 pengaruh parameter cuaca tidak nyata atau sangat kecil terhadap konsentrasi $\mathrm{PM}_{2.5}$. Secara umum konsentrasi $\mathrm{PM}_{2.5}$ di wilayah Jakarta bukan dipengaruhi oleh parameter cuaca, atau dapat dikatakan terdapat faktor lain yang memengaruhi konsentrasi PM2.5 (Tabel 1 dan Gambar 6).

Tabel 1. Nilai $R$-Square adj model regresi berganda antara konsentrasi $\mathrm{PM}_{2.5}$ dengan parameter cuaca

\begin{tabular}{rrr}
\hline Tahun & R Square-Adj & P-value \\
\hline 2016 & 0.2101 & 0.0505 \\
2017 & -0.1260 & 0.8908 \\
2018 & -0.0693 & 0.6922 \\
2019 & 0.0922 & 0.1941 \\
2020 & 0.0586 & 0.1557 \\
\hline
\end{tabular}




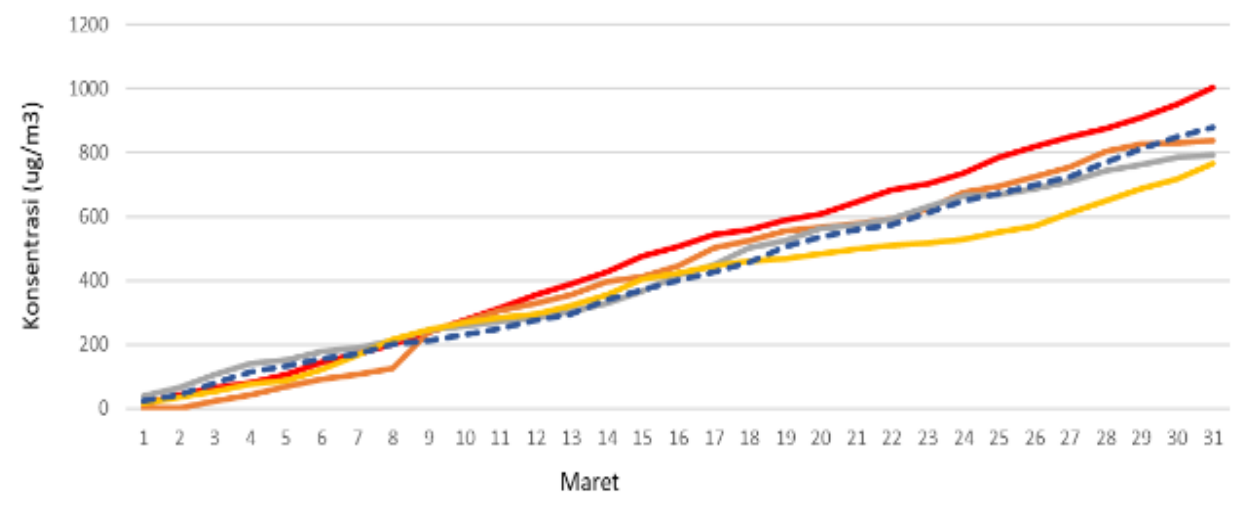

—2016 2017 -2018 $2019--2020 \quad$ Surnber : www.airnow.bov

Gambar 4. Grafik Kumulatif Konsentrasi harian Polutan $\mathrm{PM}_{2.5}$ Wilayah Jakarta Periode Bulan Maret.

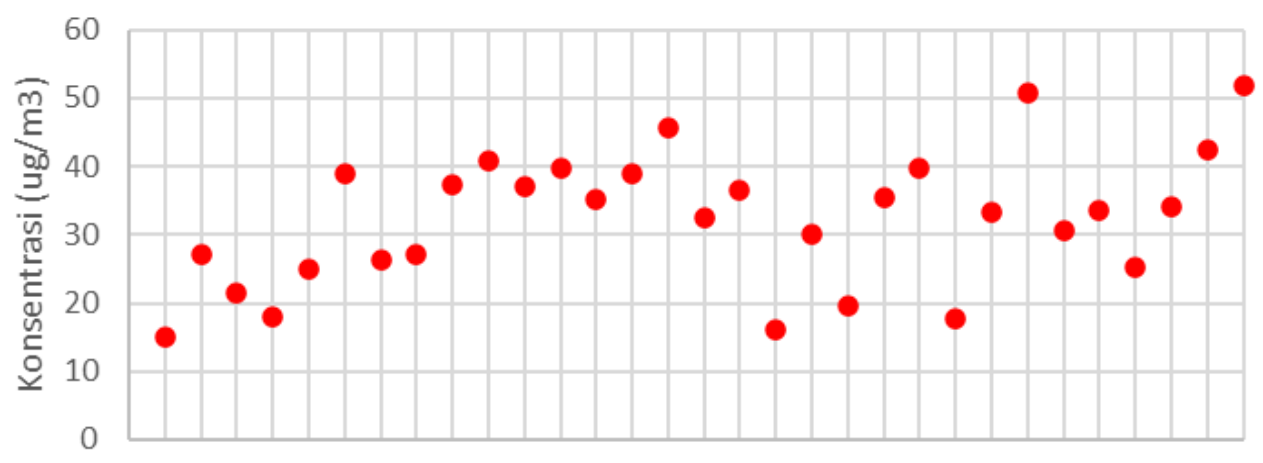

012345678910111213141516171819202122232425262728293031

tanggal

(a)

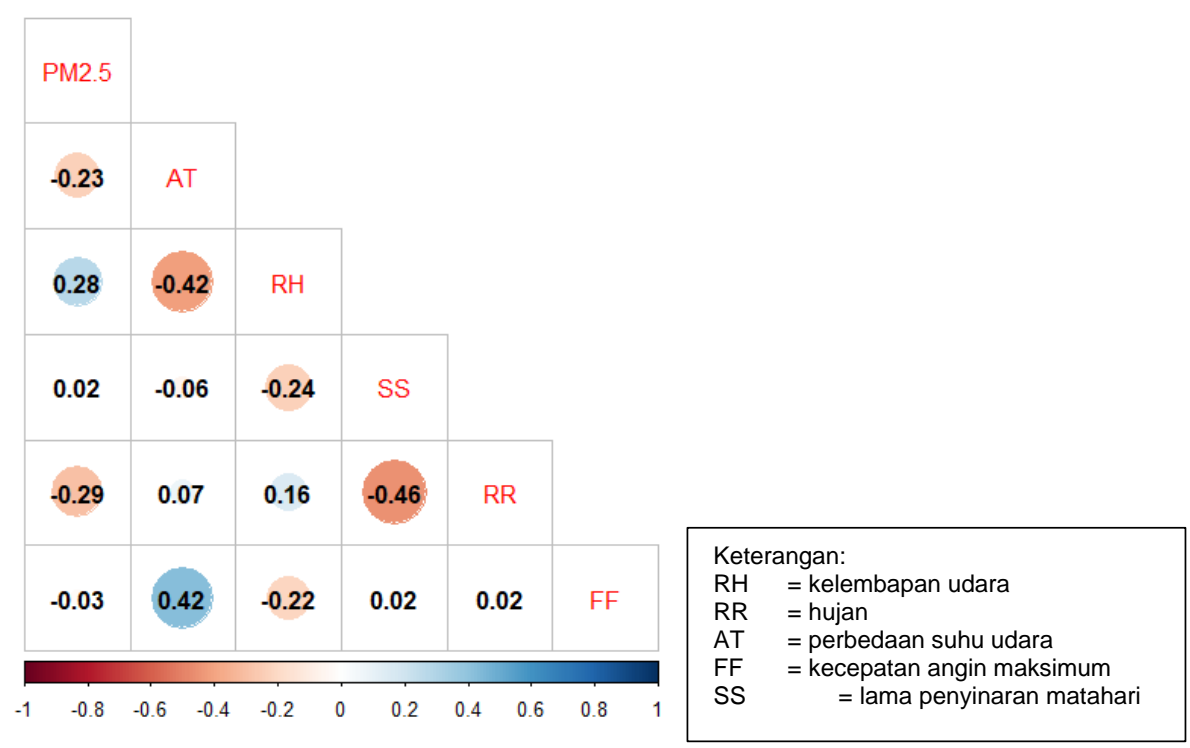

(b)

Gambar 5. (a) Sebaran konsentrasi $\mathrm{PM}_{2.5}$, (b) Nilai korelasi parameter cuaca terhadap konsentrasi $\mathrm{PM}_{2.5}$ pada Maret 2020. 


\subsubsection{Konsentrasi $C O$}

Gambar 7 merupakan grafik kumulatif konsentrasi CO di Jakarta Pusat pada periode Maret tahun 2016, 2017, 2018, 2019, dan 2020. Garis putus biru menunjukkan kumulatif konsentrasi harian CO tahun 2020 terlihat lebih rendah dibanding periode sebelumnya. Hal ini memperlihatkan bahwa penurunan konsentrasi $\mathrm{CO}$ berkorelasi terhadap pengurangan aktivitas manusia pada periode Maret 2020.

Menurut Ocak dan Turalioglu (2008) konsentrasi $\mathrm{CO}$ memiliki ketergantungan moderat terhadap parameter cuaca (kecepatan angin, suhu udara dan kelembaban). Gambar 8 menunjukkan sebaran konsentrasi $\mathrm{CO}$ pada Maret 2020 di Jakarta dan hasil korelasi antara parameter cuaca dan konsentrasi CO. Beberapa parameter cuaca terlihat memiliki korelasi namun tidak terlalu besar. Parameter lama penyinaran (SS) memiliki korelasi positif sebesar 0.2 dan parameter hujan (RR) memiliki korelasi positif sebesar 0.17 terhadap konsentrasi CO, sedangkan kecepatan angin maksimum (FF) memiliki korelasi negatif sebesar -0.24 terhadap konsentrasi $\mathrm{CO}$, sisanya yaitu perbedaan suhu $(\Delta \mathrm{T})$ dan kelembapan udara $(\mathrm{RH})$ cenderung memiliki korelasi yang sangat kecil mendekati 0 (Gambar 8b).

Hasil model regresi antara peubah bebas (parameter cuaca) dan konsentrasi CO diperoleh nilai $R$-square adj yang cukup kecil dan model yang dihasilkan tidak signifikan kecuali pada tahun 2018. Model regresi berganda yang diperoleh pada tahun 2018 cukup signifikan pada taraf signifikansi $5 \%$ dengan nilai $R$-square adj sebesar 0.3287. Hal ini menunjukkan bahwa parameter cuaca bukanlah faktor utama yang mempengaruhi konsentrasi CO di wilayah Jakarta Pusat.

Pada periode Maret tahun 2020, pengaruh parameter cuaca tidak nyata atau sangat kecil terhadap konsentrasi $\mathrm{CO}$ dengan $R$-square adj sebesar 0.0430 (Tabel 2 dan Gambar 9). Secara umum konsentrasi $\mathrm{CO}$ di wilayah Jakarta bukan dipengaruhi oleh parameter cuaca atau dapat dikatakan terdapat faktor lain yang lebih berpengaruh seperti kegiatan manusia.

Tabel 2. Nilai $R$-Square adj model regresi berganda antara konsentrasi $\mathrm{CO}$ dan parameter cuaca

\begin{tabular}{rrr}
\hline Tahun & $R$ Square-Adj & $P$-value \\
\hline 2016 & 0.0558 & 0.2746 \\
2017 & 0.0584 & 0.2683 \\
2018 & 0.3287 & 0.0090 \\
2019 & -0.1306 & 0.9041 \\
2020 & 0.0430 & 0.3080 \\
\hline
\end{tabular}

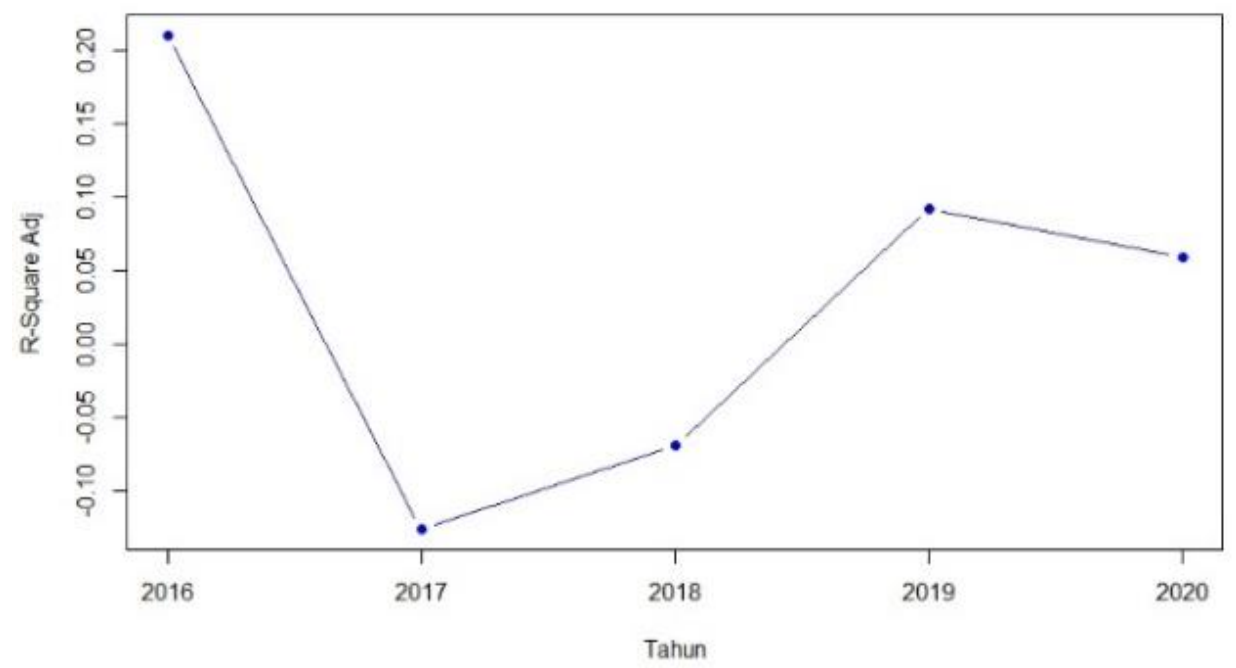

Gambar 6. $R$-square adj model regresi berganda konsentrasi $\mathrm{PM}_{2.5}$ terhadap parameter cuaca. 


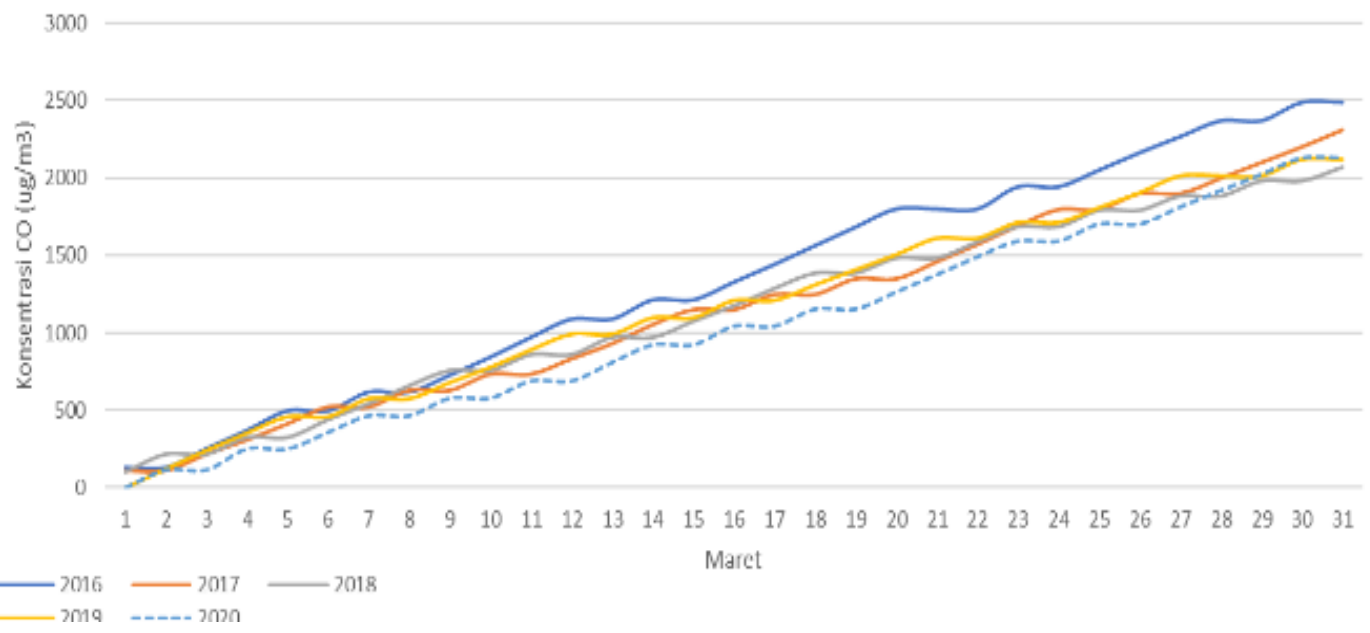

Gambar 7. Sebaran kumulatif konsentrasi CO di wilayah Jakarta pada bulan Maret 2016-2020.

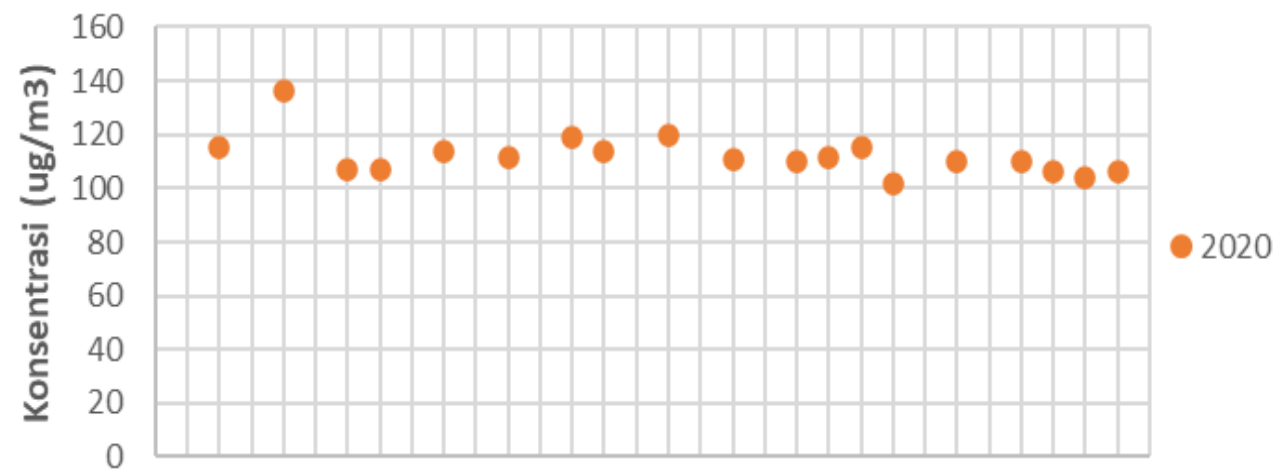

012345678910111213141516171819202122232425262728298081

(a)

Tanggal

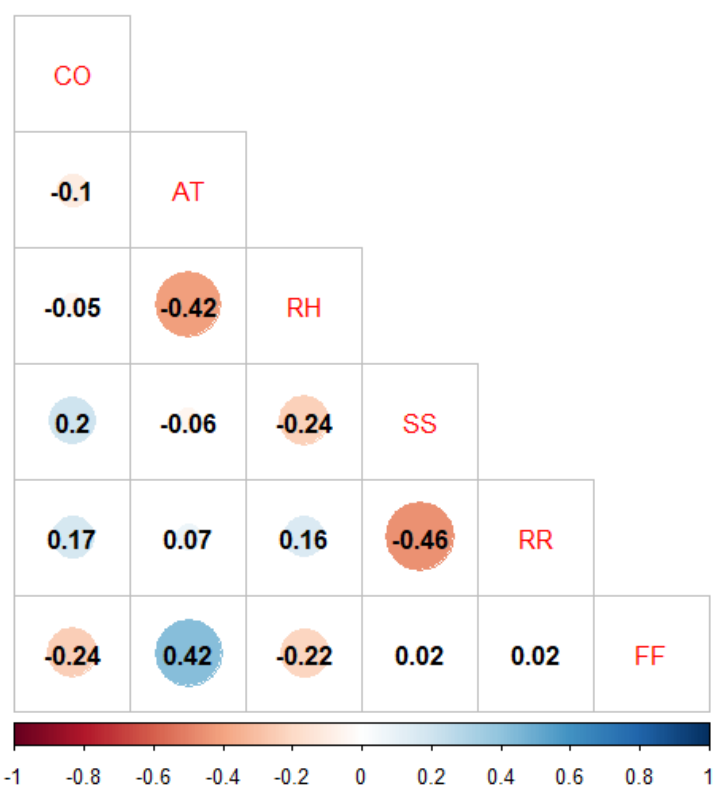

Keterangan:

$\mathrm{RH}=$ kelembapan udara

$\mathrm{RR}=$ hujan

AT = perbedaan suhu udara

FF = kecepatan angin maksimum

SS = lama penyinaran matahari

(b)

Gambar 8. (a) Konsentrasi CO di wilayah Jakarta Pusat, (b) nilai korelasi parameter cuaca terhadap konsentrasi CO pada Maret 2020. 


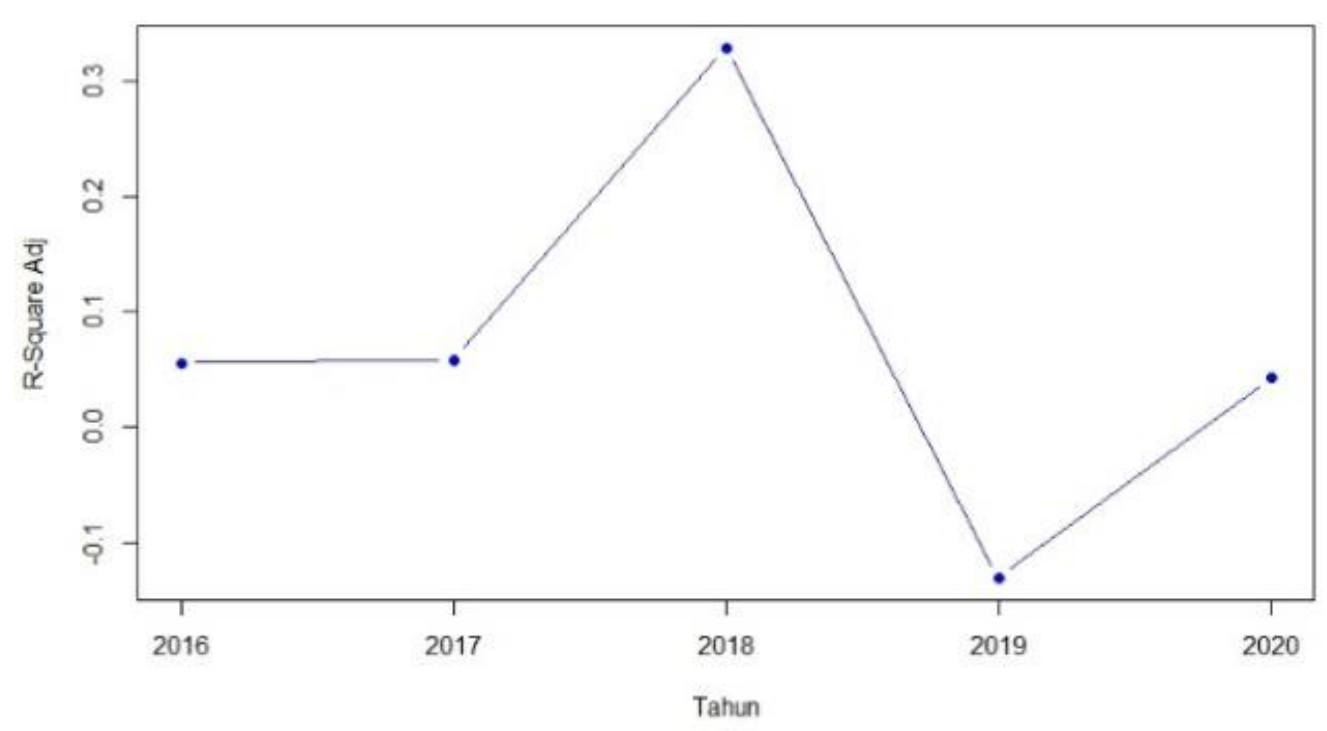

Gambar 9. $R$-square adj model regresi berganda konsentrasi $\mathrm{PM}_{2.5}$ terhadap parameter cuaca.

\section{KESIMPULAN DAN SARAN}

\subsection{Kesimpulan}

Dari hasil penelitian dapat disimpulkan bahwa indeks $I O D$ bernilai negatif disertai dengan indeks labilitas atmosfer seperti $S I, L I, K$-index, SWEAT, dan TT-index yang labil dan konvektif mengakibatkan wilayah Jakarta pada periode bulan Maret 2016, 2017, 2018, 2019, dan 2020 cukup basah, labil dan dominan tumbuh awan kumulus hingga kumulonimbus. Jika dilihat dari hubungan beberapa parameter cuaca dengan konsentrasi $\mathrm{PM}_{2.5}$ dan $\mathrm{CO}$ cukup kecil hanya sekitar 0,2-0,3.

Selama periode WFH (Maret 2020), pengaruh faktor cuaca cukup kecil terhadap pengurangan konsentrasi $\mathrm{PM}_{2.5}$ dan $\mathrm{CO}$. Pengaruh faktor lain selain cuaca kemungkinan lebih besar, seperti misalnya pembatasan aktivitas manusia yang diberlakukan di wilayah tersebut.

\subsection{Saran}

Diharapkan terdapat tulisan lain yang dapat melanjutkan penelitian tentang korelasi antara aktivitas manusia terhadap konsentrasi $\mathrm{PM}_{2.5}$ dan CO selama WFH di wilayah Jakarta.

\section{UCAPAN TERIMA KASIH}

Penulis ingin mengucapkan terima kasih kepada U.S. Air Quality Index dari website airnow.gov yang telah menyediakan data konsentrasi polutan udara. Penulis juga menyampaikan terima kasih kepada BMKG yang telah menyediakan data parameter cuaca yang digunakan dalam penelitian ini.

\section{DAFTAR PUSTAKA}

Aneja VP., Agarwal A., Roelle PA., Philips SB., Tong Q., Watkins N., Yablonsky., (2001), Measurements and analysis of criteria pollutants in New Delhi, India. Environment International, 27, 35-42.

Athoillah, I., Sibarani, R. M., \& Doloksaribu, D. (2017). Analisis Spasial El Nino Kuat Tahun 2015 dan La Nina Lemah Tahun 2016 (Pengaruhnya terhadap Kelembapan, Angin dan Curah Hujan di Indonesia). JSTMC 18(1). doi: 10.29122/jstmc.v18i1.2140

Ocak, S., \& Turalioğlu, F.S. (2008). Effect of Meteorology on the Atmospheric Concentrations of Traffic-Related Pollutants in Erzurum, Turkey. Journal of International Environmental Application and Science, 3:325-335.

Parker. (1976). Air Polution. Prentice Hall,Inc.

Parrish, DD., Trainer, M., Buhr, MP., Watkins, BA., Fehsenfeld, FC. (1991). Carbon Monoxide Concentrations and their Relation to Concentrations of Total Reactive Oxidized Nitrogen at Two Rural US sites. Journal of Geophysical Research. Vol.96: 9309-9320

Pemprov DKI. (2017). Rencana Pembangunan Jangka Menengah Daerah Provinsi DKI Jakarta 2017-2022. DKI Jakarta.

Shukla, J. B., Misra, A. K., Sundar, S., \& Naresh, R. (2008). Effect of rain on removal of a gaseous pollutant and two different particulate matters from the atmosphere of a city. Math. Comput. Model, 48(5-6): 832844. doi: $10.1016 / \mathrm{j} . \mathrm{mcm} .2007 .10 .016$

Rizi, U.F.D., Suradi, Sunaryo, \& Agus, A. (2019). Analisis Dampak Diterapkannya Kebijakan Working From Home Saat Pandemi Covid19 terhdapa Kondisi Kualitas Udara di Jakarta. Jurnal Meteorologi Klimatologi dan 
Geofisika, 6(3). doi: 10.36754/jmkg.v6i3.141

Vallero, D. A. (2014). Fundamentals of air pollution. Edisi ke 4. London: Academic press.

Xu, D. Q., \& Zhang, W. L. (2004). Monitoring of pollution of air fine particles (PM2.5) and study on their genetic toxicity. Biomedical and environmental sciences, 17(4): 452458.

Yananto, A., \& Sibarani, R.M. (2016). Analisis Kejadian El Nino dan Pengaruhnya Terhadap Intensitas Curah Hujan Di Wilayah Jabodetabek (Studi Kasus :
Periode Puncak Musim Hujan Tahun 2015/2016). JSTMC, 17(2): 65-73. doi: 10.29122/jstmc.v17i2.541

Zahroh, N.F., Dewi, N.W.S.P., \& Harsanti, D. (2017). Indeks Labilitas Udara untuk Memprediksi Kejadian Badai Guntur pada Puncak Musim Hujan Tahun 2016. JSTMC, 18(1). doi: 10.29122/jstmc.v18i1.1764

Zhang, H., Wang, Y., Hu, J., Ying, Q. dan Hu, X.M. (2015). Relationships between meteorological parameters and criteria air pollutants in three megacities in China. Environ. Res., 140: 242-254. doi: 10.1016/j.envres.2015.04.004 